\title{
Megaparks for metapopulations: Addressing the causes of locally high elephant numbers in southern Africa
}

\author{
Rudi J. van Aarde ${ }^{a}$ and Tim P. Jackson ${ }^{a}$ \\ ${ }^{\mathrm{a} C o n s e r v a t i o n ~ E c o l o g y ~ R e s e a r c h ~ U n i t, ~ D e p a r t m e n t ~ o f ~ Z o o l o g y ~ a n d ~ E n t o m o l o g y, ~}$ \\ University of Pretoria, Hatfield 0028, South Africa
}

\begin{abstract}
Conservation management options for southern African elephants range from local to regional scales. Here we review these options and argue in favour of actions that will deal with the causes rather than symptoms of elephant numbers that are locally high. Metapopulation theory ensures population persistence, while our approach extends this in order to stabilise elephant numbers regionally. By allowing for the development and maintenance of regional sinks, we may also limit numbers in sources. This application of the metapopulation metaphor is a powerful ecological platform from which to manage elephant numbers and impact through southern Africa. Our approach engages the causes of the apparently high abundance of elephants in parts of southern Africa. It moves away from the practice of dealing only with numbers (symptoms) when managing the impact of elephants on other species. While providing an ecological basis for the development of elephant management options, this needs to be melded with social, political and economic realities through southern Africa. In this regard we are encouraged by the ongoing development of several Transfrontier Conservation programmes and Peace Parks across the region.
\end{abstract}

\section{Article Outline}

1. Introduction

2. The present scenario

3. Past and present management practices deal with symptoms

3.1. Culling

3.2. Contraception

3.3. Translocation

3.4. Do nothing

4. Consequences of control

5. Addressing the causes of the problem

6 . The metapopulation metaphor

6.1. Habitat vacancy 
6.2. Dispersal and range use

6.3. Asynchrony in dynamics

7. From theory to practice

Acknowledgements

References

\section{Introduction}

The management of Africa's elephants is complex - they are vulnerable to extinction in some regions but appear over-abundant in others (Blake and Hedges, 2004 and Stephenson, 2004). Overall, southern Africa's populations grew significantly from 1994 to 2002 (Blanc et al., 2005) and this trend probably continues. Across the sub-region, increasing elephant numbers may threaten other species and their habitats (Chafota and Owen-Smith, 1996, Lombard et al., 2001 and Whyte et al., 2003), while elephants that roam beyond conservation areas come in to conflict with people (e.g. Barnes, 1996, Hoare, 1999, Osborn and Parker, 2003 and Sitati et al., 2005). It is not surprising that elephant management has fuelled well-worn debates for almost half a century.

The elephant problem, as it is known, has its roots in the locally high numbers of elephants in conservation areas and their perceived consequences for vegetation (see Pienaar et al., 1966, van Wyk and Fairall, 1969, Brooks and Buss, 1962, Caughley, 1976, Hanks, 1979, Barnes, 1983 and Foggin, 2003). More specifically, such high numbers have been blamed for degrading vegetation to the detriment of other species (e.g. Buechner and Dawkins, 1961, Laws, 1970 and Caughley, 1976). Factors that cause locally high numbers are induced principally by people and include water supplementation, fencing and the reduction and fragmentation of landscapes that detract from more natural movements of elephants. More recently the focus on elephants has broadened in both scientific and political circles to include conflict between humans and elephants.

Management practices that address local impact by curbing high numbers actually deal with the symptoms and not the underlying causes of the elephant problem. Here, we advance an approach that addresses the causes of locally high elephant numbers using elephant spatio-temporal dynamics. Specifically, we advocate applying metapopulation principles to elephant management as this could limit numbers at a regional scale while also reducing their local ecological impact. In addition, we advocate changing management practices that lead to locally high numbers and interfere with spatiotemporal dynamics.

Traditionally metapopulation theory ensures population persistence (e.g. Hanski, 1999, Broome, 2001, Ferreras, 2001, Wikramanayake et al., 2004 and Hellgren et al., 2005). Here we extend this approach to manage local numbers of an abundant species, the 
savanna elephant (Loxodonta africana), across the southern African sub-continent. Essentially, we may reduce impact by allowing dispersal from sources into sinks.

\section{The present scenario}

While elephants are widely distributed over sub-Saharan Africa this once continuous population is now fragmented and often confined to formal protected areas that account for only $16 \%$ of their distributional range (see Blanc et al., 2003). Today, almost $70 \%$ of Africa's elephants occur in southern Africa (Blanc et al., 2003). Here many populations are increasing at rates of $4-5 \%$ per annum, while in small reserves rates of increase are often higher (Slotow et al., 2005).

Elephants are long-lived and we have little understanding of the factors that limit populations. We know that survival amongst adults is high (Owen-Smith, 1983) but varies considerably for sub-adults $<10$ years old (Leuthold, 1976 and Haynes, 1987; Shrader et al., unpublished data). Poaching (Stiles, 2004) and periodic droughts (see Walker et al., 1987 and Dudley et al., 2001) challenge survival while protection and the provisioning of water may enhance population growth.

Dispersal may also limit elephant populations (Chafota and Owen-Smith, 1996), though fences impair movement. Fences enclose several reserves, demarcate international borders and act as veterinary cordons. Human settlements around reserves also provide effective barriers to movements (see Hoare and du Toit, 1999) that could compromise dispersal. When confined, protected, or provided with water elephant densities reach levels that may adversely affect vegetation (see Gaylard et al., 2003, Whyte et al., 2003, Skarpe et al., 2004 and de Beer et al., 2006) and transform landscapes (see Western and Gichohi, 1989, Dublin et al., 1990, Herremans, 1995, Cumming et al., 1997, Gillson and Lindsay, 2003, Pickett et al., 2003 and Western and Maitumo, 2004). Given this scenario, controlling local elephant numbers may reduce the degradation of vegetation (see Chafota and Owen-Smith, 1996, Whyte et al., 1999 and Whyte, 2004). Alternatively, there may be no ecological basis for artificially controlling elephant numbers (see Gillson and Lindsay, 2003 and Skarpe et al., 2004).

\section{Past and present management practices deal with symptoms}

Early approaches to conservation management focused on numbers (Hanks et al., 1981). For instance active management by the addition of water and manipulation of fire may have instigated changes in the ranging behaviour of herbivores and induced high local impacts (Owen-Smith, 1996, Gaylard et al., 2003, Grainger et al., 2005 and de Beer et al., 2006). Historical sentiment primarily considered management issues at a political and not a conservation level (see Buss, 1977 and Cumming, 1981), thereby distancing conservation practices from our present day understanding that conservation should focus on maintaining heterogeneity (e.g. Rogers, 2003).

Elephant management aimed to stabilise numbers at levels for which it was assumed that vegetation would not be degraded, thereby maintaining biodiversity (Caughley, 1983, 
Walker et al., 1987 and Gillson and Lindsay, 2003). The concept of economic carrying capacity supports this practice (Caughley, 1983 and Gillson and Lindsay, 2003) and consequently agricultural rather than ecological paradigms drove many early management actions. These included measures to increase and then stabilise numbers at levels below their so-called carrying capacity. Consequently, elephant numbers in some southern African parks were reduced to levels considered lower than those dictated by ecological carrying capacity. Under these circumstances, resources no longer limited numbers (Chafota and Owen-Smith, 1996 and Gillson and Lindsay, 2003). Those that thought this would maintain woodlands clearly ignored the many other factors that induce changes across woodlands (e.g. Pickett et al., 2003).

Some consider landscape transformation as detrimental for the conservation of biological diversity. In doing so they ignore that many woodlands developed in response to historical disturbances driven by man (see Walker, 1989). Here the ivory trade was pivotal as it decimated elephant populations and reduced their impact on woodlands. This could have been amplified by the rinderpest pandemic that devastated browser populations across eastern and southern Africa, thereby providing for the further development of woodlands (see Prins and van der Jeugd, 1993 and van de Koppel and Prins, 1998). From here stems the misconception that woodlands must be maintained (e.g. Skarpe et al., 2004). This mind set would certainly make elephants a problem as many people enjoy woodlands for their aesthetic values. Despite this history, elephant management often involved the control of numbers. Before setting out our ideas to address the underlying causes of the elephant problem we briefly evaluate the success of culling, contraception and translocation in controlling numbers, as well the economic, ethical and logistical constraints of these methods.

\subsection{Culling}

With the adoption of culling during the mid-1960s, elephant target densities were set arbitrarily (van Wyk and Fairall, 1969 and Laws et al., 1970) - densities supported by the concept of economic carrying capacity. This pre-dated the modern ethos that landscape diversity moulds population numbers. Culling targets were therefore whimsical and had no theoretical basis (see Caughley, 1983 and Owen-Smith, 1983).

Culling may disrupt population dynamics. For instance, culling may give rise to immigration. This occurred in the Kruger National Park, where movement into culled areas increased numbers (van Aarde et al., 1999). In this case, the increase in densities after culling (van Aarde et al., 1999) may have intensified the local impact of elephants. Culling is only effective in limiting growth when applied continuously. For instance, following the cessation of culling in the Kruger, growth rates increased dramatically (see Whyte et al., 2003). Since the cessation of culling in 1995 elephant numbers in Hwange National Park (Zimbabwe) almost doubled in just six years, while elsewhere in Zimbabwe numbers grew about 28\% over the same period (Foggin, 2003). Even so culling does reduce numbers, albeit temporarily. 
Selective culling targeting bulls or animals of certain age classes also may distort age structures and enhance, rather than suppress growth rates (see Gordon et al., 2004) and so negate the intention of culling. In addition, at lower densities population growth rate may increase (see Sinclair, 2003), so culling could effectively increase growth rate.

\subsection{Contraception}

Birth control has been hailed as a tool to limit elephant numbers. We can control birth rates with hormones and their derivates, or with immuno-contraceptives (Pimm and van Aarde, 2001). Contraceptives may lengthen inter-calving intervals or increase the age of first calving (Dobson, 1993). This could reduce population growth and the impact that further increases in numbers can have for vegetation. Unlike culling, contraception does not reduce elephant numbers - instead it relies on natural mortality.

Contraception, like culling, raises ethical questions, especially when unplanned sterilization of cows excludes them from the gene pool (Whyte et al., 1998) and induces abortion (see Allen et al., 2002). Moreover, despite initial optimism, all contraceptives may have side effects on the health and behaviour of cows (Whyte et al., 1998 and Pimm and van Aarde, 2001). Hormonally treated cows may remain in sexual heat and be harassed by bulls (Whyte and Grobler, 1997). Reducing reproductive rates may also destabilise the age and social structures of breeding herds and possibly influence the wellbeing of cows and their calves (see McComb et al., 2001 and Pimm and van Aarde, 2001).

While we may debate the ethics of contraception, the limitations imposed by the logistics of such a programme are more tangible. The efforts needed to stabilise elephant numbers in large populations through birth control are not realistic. They are both laborious and costly (Pimm and van Aarde, 2001). At the population level, birth control is constrained by the number of females needing treatment (Whyte et al., 1998). For instance, age at first calving will only increase effectively if almost 50\% of pregnant cows less than 15 years old are on birth control or forced to abort (Dobson, 1993). Worse, in Kruger, growth will only stabilize at zero if we treat nearly $75 \%$ of adult cows continuously for 11 years (van Aarde et al., 1999). To effectively maintain zero growth contraception would need to be ongoing. Treated cows need to be marked individually in order to locate them for booster treatment. Most African countries do not have the finances or infrastructures to sustain such operations (see Pimm and van Aarde, 2001). Indeed, we agree with Bertschinger et al. (2003) who concluded that immuno-contraception is only suitable for small, confined populations.

\subsection{Translocation}

While ethically appealing, translocation is not a practical solution to reduce numbers in large populations. Transporting elephant herds is both costly and cumbersome (Foggin, 2003 and Hofmeyr, 2003). More importantly, few existing conservation areas in southern Africa can accommodate extra elephants (Hofmeyr, 2003 and Whyte, 2004), while smallscale translocations to other continents are fraught with ethical issues (Roberts and 
Travers, 2004). On several reserves, reintroduced elephants have exhibited behavioural abnormalities, due mainly to disrupted social structure (Slotow et al., 2000, Garaï et al., 2004 and Bradshaw et al., 2005). To be effective, translocation must also continue for as long as managers wish to keep local numbers at specific levels.

In turn, we must even manage translocated populations to prevent undesirable impact particularly as most translocations are from larger to smaller reserves (Garaï et al., 2004). Most of the 30 populations founded on small estates across South Africa over the past 20 years now need control (Slotow et al., 2005). We conclude that translocating elephants cannot limit numbers, either in a target area or across the region.

\subsection{Do nothing}

Historically, crisis management rather than evidence-based management clouded elephant conservation (Lindsay, 2003). The obvious alternative is to do nothing. Some argue that this approach provides the best compromise solution, however, politically unacceptable this might seem (see Griffiths, 2004). In principal, we do not agree with this approach for systems that are manipulated or artificially isolated. Under such conditions it is only by altering population numbers in a controlled way and closely monitoring the responses of populations that we can hope to understand the outcomes of our management actions (see Pullin et al., 2004). Consequently "doing nothing” does not advance our understanding of management. While many elephant-related studies have been conducted, comprehensive studies using replicated, controlled designs are few. We need such information in order to make informed management decisions.

\section{Consequences of control}

Stabilizing elephant numbers may induce complications, given that African savannas are not stable. Here disturbances modulate resilience and resistance (Walker, 1989, Rogers, 2003, Scholes et al., 2003, Gillson and Lindsay, 2003 and Gillson, 2004a). Elephants disturb savannas (see Western, 1989) and static numbers may compromise local habitat heterogeneity and species richness (Walker et al., 1987, Cumming et al., 1997, Gillson and Lindsay, 2003 and Whyte et al., 2003). Static numbers may also reduce the spatial patchiness that buffers species against drought (Illius and O'Connor, 2000). Savannas may not benefit, therefore, from static elephant numbers - ultimately, resilience may be weakened (Caughley, 1983, Walker et al., 1987, Illius and O’Connor, 2000 and Ogutu and Owen-Smith, 2003). While we can theorise, it is impossible to specify elephant densities that do not interfere with biological diversity (Chafota and Owen-Smith, 1996, Ben-Shahar, 1997 and Whyte et al., 2003). We, like others, argue that maintaining elephant numbers at predefined levels is not a sensible management goal. Indeed, numbers should vary, through both space and time in response to both density dependent and environmental forces (Bulte et al., 2004 and Gillson et al., 2005). 


\section{Addressing the causes of the problem}

Conservation actions derived from population and landscape principles could address the causes of the elephant problem. Therefore, where possible, we need to focus on restoring forces that limit elephant numbers and modulate their impacts on vegetation under natural conditions. To deal with the causes of the problem means we need to tackle the artificial manipulation of limiting resources. Here, specifically, we address the other key aspects central to the issue of locally high elephant numbers - range fragmentation and restriction. To do so we must reinstate dispersal as a process that moderates densities both temporally and spatially. This calls for an ecological framework against which to develop and assess the outcomes of such elephant management. Inherently, such a paradigm will address the persistence and diversity of system processes where elephants occur.

Gillson and Lindsay’s (2003) proposal for a non-equilibrium approach offers a fresh theoretical basis for elephant management. At the appropriate temporal and spatial scales their approach becomes even more attractive (see Gillson, 2004b and Bulte et al., 2004). It is also consistent with our understanding of the African savanna in a non-equilibrium state (Dublin et al., 1990, Gillson, 2004a, Gillson, 2004b, Skarpe et al., 2004 and Birkett and Stevens-Wood, 2005). A non-equilibrium approach focuses on demographic and ecological processes, recognizing the interactive role of elephants in savanna systems. We wish to augment Gillson and Lindsay’s (2003) approach by adding the metapopulation metaphor as a platform to manage the elephant problem across southern Africa.

\section{The metapopulation metaphor}

Metapopulation theory (Hanski, 1999) provides a conceptual framework for population management (Groot-Bruinderink et al., 2003 and Hanski, 2004). The metapopulation is one of several models that explore demographic responses to spatial scale (see Thomas and Kunin, 1999). It relies on the spatial discontinuities in a population imposed by landscape heterogeneity. Following local extinctions, the dynamics of sub-populations differ enough to induce dispersal and the recolonisation of patches. Under these conditions, local populations are driven by dispersal events. Local populations could fluctuate in numbers, while the sum total of numbers across the region will remain relatively stable (Pulliam, 1988).

Dispersal may also be intrinsic, due to differences in landscape quality, and therefore differences in source and sink habitats (Dias, 1996). Here, mortality in sinks will occur deterministically and provides a mechanism through which populations could be limited across regions (e.g. Novaro et al., 2005). We may arrange such demographic responses along two axes that combine per capita birth-death and emigration-immigration rates (Thomas and Kunin, 1999). The classical metapopulation functions at the point where the sum total of the differences between births and deaths, and between immigration and emigration is zero - in other words where the regional population is stable despite local instabilities. 
Catering for landscape heterogeneity is important as it provides the key processes that maintain populations across space and time. To operate, metapopulations essentially require vacant habitats, dispersal between these, and asynchrony in the dynamics of the local populations. Here we argue that these conditions hold for elephants across southern Africa.

\subsection{Habitat vacancy}

Since the end of the 19th century elephant range has declined dramatically throughout Africa (Brooks and Buss, 1962, Parker and Graham, 1989, Roth and Douglas-Hamilton, 1991 and Stephenson, 2004). Currently, elephants occur over some 5 million $\mathrm{km}^{2}$ and well beyond the boundaries of protected areas, which account for only $16 \%$ of their range (Blanc et al., 2003). Elephant ranges, however, are poorly documented - in southern Africa for instance, they are believed to extend over $\sim 1.7$ million $\mathrm{km}^{2}$ of which only $39 \%$ has been confirmed (Blanc et al., 2003). At a continental scale, up to $50 \%$ of potential elephant range has not been surveyed and only $15 \%$ is covered by systematic surveys (Blanc et al., 2003).

Clearly, we have a very poor understanding of elephant ranges. Presently, elephants do not occupy all potential range across southern Africa. In some areas people inhabit land not occupied by elephants (Hoare and du Toit, 1999), while in others they share their land with elephants. Often overlooked is the fact that across much of southern Africa human densities seldom exceed five persons per $\mathrm{km}^{2}$ (Mittermeier et al., 2003). Much of this land is relatively untransformed (Mittermeier et al., 2003) and, given the opportunity, could be colonised by elephants. These areas incorporate private land, communal land, forest reserves and wildlife management areas - vacant habitats that are key to metapopulation dynamics.

\subsection{Dispersal and range use}

The present distribution of elephants is patchy, though most occur in conservation areas. They disperse readily into vacant habitats. For instance, historical records show that elephants moved from Mozambique into South Africa's Kruger National Park, which in the early 1900s supported fewer than 10 elephants. Dispersal at annual rates of 7-10 km meant that the Park's 20,000 km² was colonised within 50 years (Whyte et al., 2003). Similarly, in 1955 elephants were recorded in the Serengeti National Park (Tanzania) after an absence of at least 40 years. Here numbers increased over a 10 -year period, mainly through immigration, to some 2000 individuals (Lamprey et al., 1967).

In other areas, where managers manipulated water availability, elephant populations expanded rapidly and at rates that exceed their reproductive capacity. For instance, Etosha National Park's population approximated 50 individuals in 1950 and increased to some 2000 by 1980 (see Lindeque and Lindeque, 1991). Following water supplementation in the Khaudum Game Reserve (Namibia), its population increased from around 80 in 1976 to some 3400 in 2004 (B. Beytell, pers. commn.). Civil unrest in southern Angola may have contributed to this increase in Khaudum, which at $\approx 13 \%$ per 
year is almost double that typical of populations with a stable age structure (see Calef, 1988).

In Kruger, culling induced dispersal of elephants onto areas where densities were reduced (van Aarde et al., 1999). It follows that elephants do disperse when given the opportunity or when circumstances allow. This is critical to the application of the metapopulation model to the conservation management of elephants, since the metapopulation can only operate with dispersal.

\subsection{Asynchrony in dynamics}

Within southern Africa elephant population growth rates differ. Numbers fluctuate when populations are driven by local events, such as droughts, outbreaks of disease and disturbances induced by people (Leuthold, 1976, Haynes, 1988, Lindeque, 1991 and Dudley et al., 2001). Most widespread is the apparent increase over a five-year period of elephant numbers in conservation areas including the Kruger, northern Botswana and Khaudum Game Reserve (Blanc et al., 2005). Over the same time period, in other areas such as Etosha National Park (van AStephenson, 2004arde et al., 2003), the Caprivi Region in Namibia (Blanc et al., 2005), Hwange National Park (S. Chamaillé-Jammes, unpublished data) and Sebungwe in Zimbabwe (Blanc et al., 2005) numbers appear relatively stable. Particularly through Zambia's national parks, including South Luangwa and Kafue and in Malawi's Kasungu National Park, elephant numbers may have declined over recent years (see Blanc et al., 2005, Ferreira et al., 2005 and Guldemond et al., 2005). This variation in trends may partly be ascribed to intra- as well as inter-population differences in inter-calving intervals, ages at sexual maturity and survival rates. Thus, population numbers vary in time, both between and within southern Africa's elephants.

\section{From theory to practice}

We support the development of one or more networks of conservation areas that will allow the southern African sub-region's elephants to be driven by metapopulation dynamics. Inevitably, our model must provide for both source and sink populations. This can be achieved by allowing dispersal from sources, including many existing conservation areas, to sinks. In doing so, our approach links source populations within a megapark context. We advocate that the landscape matrices between conservation areas act primarily as sinks. By the very nature of sinks, here elephant mortality rates must be greater than birth rates, while populations are maintained by immigration from sources. Such immigration should limit numbers in source populations. In restoring this type of metapopulation structure, elephant numbers could be prevented from increasing locally to levels that are deemed undesirable in sources.

Sink populations must be limited and while we advocate natural control, there may be a need for people to reduce numbers in sinks. We see this as natural given that human predation is considered a major historical source of impact on elephant numbers (Surovell et al., 2005). To manage sinks effectively local communities could be allowed to hunt elephants in a controlled and authorised manner. This must be seen in the context of 
sustainable resource use and must provide tangible benefits (for instance in the form of meat or revenue from sports hunting) to these communities. Ultimately, maintaining sink areas effectively will benefit regional elephant conservation. It is unclear how sinks will perform, or even whether they will need overt management. These issues need thorough investigation before implementing a metapopulation approach to manage regional elephant numbers.

By defragmenting the landscape and encouraging elephant range expansion, our metapopulation approach addresses the underlying causes of locally high elephant numbers. While metapopulation theory may underlie wildlife population dynamics elsewhere in Africa (for instance of wildebeest Connochaetes taurinus in the Serengeti/Mara system; see Sinclair, 2003), this paradigm has not been advanced formally as a management tool to limit numbers regionally. Perhaps Owen-Smith (1983) advocated the most similar approach when he put forward the idea of creating dispersal sinks for white rhinoceros Ceratotherium simum in the form of "vacuum zones", where off-take was controlled - though his idea was specifically conceived for enclosed areas. In essence, we encourage the maintenance of a widely distributed elephant population, where the demographics and dynamics of sub-populations differ across space and time. Here, the dynamics of these sub-populations should be managed within a metapopulation framework. To do so, we envisage a conservation matrix comprising a range of land use options across international boundaries at a sub-continental scale.

To achieve this goal we must develop a far better understanding of the spatial, population and conflict dynamics of elephants within southern Africa, as well as the consequences of defragmenting populations for the spread of contagious disease (see Hess, 1994).

Conceptually, our ideas are at variance with management practices such as fencing, the provisioning of artificial water, culling in source areas and contraception. Conversely, our approach has a relatively simple ecological platform, which considers the population as a spatial entity. From a social perspective the establishment of megaparks will inevitably meet with negative sentiment from local communities, as people are naturally concerned about the increase in elephant numbers outside formal reserves (see O'Connell-Rodwell et al., 2000). These people can only be expected to support this conservation idea if the benefits of elephants outweigh the perceived costs (see Gillingham and Lee, 2003) addressing this issue must be integrated in the establishment of megaparks (also see Newmark et al., 1994). Furthermore, before implementation and for the megapark approach to be effective, decision-makers need to be informed of its sound scientific basis (see Pullin et al., 2004).

Nevertheless, the development of the network of conservation areas we envisage for southern Africa, is a reality. The process is complex and involves local government authorities, national wildlife management agencies, non-governmental organizations and local communities. It underlies international collaboration and the ethos of Peace Parks and the establishment of Transfrontier Conservation Areas (TFCAs) (see Hanks, 2001, Wynberg, 2002 and Western, 2003). From a political and financial standpoint, the Southern African Development Community supports these initiatives and plans are in place for the establishment of several TFCAs throughout southern Africa. For example, 
in 2002 an agreement was signed by member countries to create the Greater Limpopo Transfrontier Park. This will eventually unite major conservation areas and adjoining landscape matrices in Mozambique, South Africa and Zimbabwe. The proposed Kavango-Zambezi Transfrontier Conservation Area (KAZA TFCA) involves five countries and incorporates 36 national parks, game reserves and wildlife management areas. It extends over an area of more than $300,000 \mathrm{~km}^{2}$ that supports about 200,000 elephants. To put this into perspective, this is an area some 20 times larger than the Serengeti National Park, while the KAZA TFCA contains about one third of all Africa's elephants.

By allowing elephant numbers to fluctuate locally through dispersal, we may reduce impact on vegetation and other taxa. Under our scenario, conservation areas serve as components of a regional landscape mosaic, not as isolated entities in which elephants must occur all the time in "acceptable" numbers. This relieves individual parks of the onus to stabilise local elephant populations. Consequently, transient changes within regional conservation clusters would represent a shifting mosaic of resources over space and time. We propose conservation managers should accept local instability of elephant numbers, as long as relative stability can be assured through regional conservation initiatives. Such an option develops regional conservation initiatives that focus on elephants - it makes ecological sense and should have political, sociological and economic benefits.

\section{References}

Allen et al., 2002 W.R. Allen, S.S. Mathias, F.B.P. Wooding, J.A. Skidmore and R.J. van Aarde, Placentation in the African elephant, Loxodonta africana. 1. Endocrinological aspects, Reproduction 60 (2002), pp. 105-116.

Barnes, 1983 R.F.W. Barnes, The elephant problem in Ruaha National Park, Tanzania, Biological Conservation 26 (1983), pp. 127-148.

Barnes, 1996 R.F.W. Barnes, The conflict between humans and elephants in the Central African Forests, Mammal Review 26 (1996), pp. 67-80.

Ben-Shahar, 1997 R. Ben-Shahar, Elephants and woodlands in northern Botswana: how many elephants should be there?, Pachyderm 23 (1997), pp. 41-43.

Bertschinger et al., 2003 Bertschinger, H.J., Kirkpatrick, J.F., Fayrer-Hosken, R.A., Grobler, D., van Altena. J.J., 2003. Immunocontraception of African elephants using porcine zona pellucida vaccine. In: Proceedings of the First Workshop on the Control of Wild Elephant Populations. Utrecht University, Netherlands. $<$ http://elephantpopulationcontrol.library.uu.nl/paginas/txt06.html> (accessed 5 April 2006). 
Birkett and Stevens-Wood, 2005 A. Birkett and B. Stevens-Wood, Effect of low rainfall and browsing by large herbivores on an enclosed savannah habitat in Kenya, African Journal of Ecology 43 (2005), pp. 123-130.

Blanc et al., 2003 J.J. Blanc, C.R. Thouless, J.A. Hart, H.T. Dublin, I. Douglas-Hamilton, C.G. Craig and R.F.W. Barnes, African Elephant Status Report 2002, International Union for the Conservation of Nature, Gland (2003).

Blanc et al., 2005 J.J. Blanc, R.F.W. Barnes, C.G. Craig, I. Douglas-Hamilton, H.T. Dublin, J.A. Hart and C.R. Thouless, Changes in elephant numbers in major savanna populations in eastern and southern Africa, Pachyderm 38 (2005), pp. 19-28.

Blake and Hedges, 2004 S. Blake and S. Hedges, Sinking the flagship: the case of forest elephants in Asia and Africa, Conservation Biology 18 (2004), pp. 1191-1202.

Brooks and Buss, 1962 A.C. Brooks and I.O. Buss, Past and present state of the elephant in Uganda, Journal of Wildlife Management 26 (1962), pp. 30-50.

Broome, 2001 L.S. Broome, Intersite differences in population demography of mountain pygmy-possums Burramys parvus Broom (1986-1998): implications for metapopulation conservation and ski resorts in Koskiuszko National Park, Australia, Biological Conservation 102 (2001), pp. 309-323.

Bradshaw et al., 2005 G.A. Bradshaw, A.N. Schore, J.L. Brown, J.H. Poole and C.J. Moss, Social trauma: early disruption of attachment can affect the physiology, behaviour and culture of animals and humans over generations, Nature 433 (2005), p. 807.

Buechner and Dawkins, 1961 H.K. Buechner and H.C. Dawkins, Vegetation change induced by elephants and fire in Murchison Falls National Park, Uganda, Ecology 42 (1961), pp. 752-766.

Bulte et al., 2004 E. Bulte, R. Damania, L. Gillson and K. Lindsay, Space - the final frontier for economists and elephants, Science 306 (2004), pp. 420-421.

Buss, 1977 I.O. Buss, Management of big game with particular reference to elephants, The Malayan Nature Journal 31 (1977), pp. 59-71.

Calef, 1988 G.W. Calef, Maximum rate of increase in the African elephant, African Journal of Ecology 26 (1988), pp. 323-327.

Caughley, 1976 G. Caughley, The elephant problem - an alternative hypothesis, East African Wildlife Journal 14 (1976), pp. 265-283.

Caughley, 1983 G. Caughley, Dynamics of large mammals and their relevance to culling. In: R. Owen-Smith, Editor, Management of Large Mammals in African Conservation Areas, Haum Educational Publishers, Pretoria, South Africa (1983). 
Chafota and Owen-Smith, 1996 J. Chafota and N. Owen-Smith, Options for the management of elephants in northern Botswana, Pachyderm 22 (1996), pp. 67-71.

Cumming, 1981 D.H.M. Cumming, The management of elephant and other large mammals in Zimbabwe. In: P.A. Jewell and S. Holt, Editors, Problems in Management of Locally Abundant Wild Mammals, Academic Press, New York (1981), pp. 91-118.

Cumming et al., 1997 D.H.M. Cumming, M.B. Fenton, I.L. Rautenbach, R.D. Taylor, G.S. Cumming, M.S. Cumming, J.M. Dunlop, G.A. Ford, M.D. Hovorka, D.S. Johnston, M. Kalcounis, Z. Mahlangu and C.V.R. Portfors, Elephants, woodlands and biodiversity in southern Africa, South African Journal of Science 93 (1997), pp. 231-236.

de Beer et al., 2006 Y. de Beer, W. Kilian, W. Versfeld and R.J. van Aarde, Elephants and drought changing woody vegetation in Namibia's Etosha National Park, Journal of Arid Environments 64 (2006), pp. 412-421.

Dias, 1996 P.C. Dias, Sources and sinks in population biology, Trends in Ecology and Evolution 11 (1996), pp. 326-330.

Dobson, 1993 A.P. Dobson, Effect of fertility control on elephant population dynamics, Journal of Reproduction and Fertility 9 (1993), pp. 293-298.

Dublin et al., 1990 H.T. Dublin, A.R.E. Sinclair and J. Mcglade, Elephants and fire as causes of multiple stable states in the Serengeti-Mara Woodlands, Journal of Animal Ecology 59 (1990), pp. 1147-1164.

Dudley et al., 2001 J.P. Dudley, G.C. Craig, D.St.C. Gibson, G. Haynes and J. Klimowicz, Drought mortality of bush elephants in Hwange National Park, Zimbabwe, African Journal of Ecology 39 (2001), pp. 187-194.

Ferreras, 2001 P. Ferreras, Landscape structure and asymmetrical inter-patch connectivity in a metapopulation of the endangered Iberian lynx, Biological Conservation 100 (2001), pp. 125-136.

Ferreira et al., 2005 Ferreira, S., Lehman, E., Fourie, J., 2005. A survey of large mammal numbers of the Lundazi Forest Reserve, the Kasungu National Park, the Vwaza Game Reserve and the Nyika National Park. Report to the Peace Parks Foundation. Unpublished report, Conservation Ecology Research Unit, University of Pretoria, Pretoria, South Africa.

Foggin, 2003 Foggin, C., 2003. The elephant problem in Zimbabwe: can there be any alternative to culling? In: Proceedings of the First Workshop on the Control of Wild Elephant Populations, Utrecht University, Netherlands.

$<$ http://elephantpopulationcontrol.library.uu.nl/paginas/frames.html> (accessed 5 April 2006). 
Garaï et al., 2004 M.E. Garaï, R. Slotow, R.D. Carr and B. Reilly, Elephant reintroductions to small fenced reserves in South Africa, Pachyderm 37 (2004), pp. 2836.

Gaylard et al., 2003 A. Gaylard, N. Owen-Smith and J. Redfern, Surface water availability: implications for heterogeneity and ecosystem processes. In: J.T. du Toit, K.H. Rogers and H.C. Biggs, Editors, The Kruger Experience: Ecology and Management of Savanna Heterogeneity, Island Press, Washington, DC (2003), pp. 171-188.

Gillingham and Lee, 2003 S. Gillingham and P.C. Lee, People and protected areas: a study of local perceptions of wildlife crop-damage conflict in an area bordering the Selous Game Reserve, Tanzania, Oryx 37 (2003), pp. 316-325.

Gillson, 2004a L. Gillson, Testing non-equilibrium theories in savannas: 1400 years of vegetation change in Tsavo National Park, Kenya, Ecological Complexity 1 (2004), pp. 281-298.

Gillson, 2004b L. Gillson, Evidence of hierarchical patch dynamics in an east African savanna?, Landscape Ecology 19 (2004), pp. 883-894.

Gillson and Lindsay, 2003 L. Gillson and K. Lindsay, Ivory and ecology - changing perspectives on elephant management and the international trade in ivory, Environmental Science and Policy 6 (2003), pp. 411-419.

Gillson et al., 2005 L. Gillson, K. Lindsay, E.H. Bulte and R. Damiana, Elephants, ecology, and non-equilibrium? Response - we agree with Illius and Hambler et al., Science 307 (2005), p. 674.

Gordon et al., 2004 I.J. Gordon, A.J. Hester and M. Festa-Bianchet, The management of wild large herbivores to meet economic, conservation and environmental objectives, Journal of Applied Ecology 41 (2004), pp. 1021-1031.

Grainger et al., 2005 M. Grainger, R.J. van Aarde and I. Whyte, Landscape heterogeneity and the use of space by elephants in the Kruger National Park, South Africa, African Journal of Ecology 43 (2005), pp. 369-375.

Griffiths, 2004 R.A. Griffiths, Mismatches between conservation science and practice, Trends in Ecology and Evolution 19 (2004), pp. 564-565.

Groot-Bruinderink et al., 2003 G. Groot-Bruinderink, T. van der Sluis, D. Lammertsma, P. Opdam and R. Pouwels, Designing a coherent ecological network for large mammals in northwestern Europe, Conservation Biology 17 (2003), pp. 549-557.

Guldemond et al., 2005 R.A.R. Guldemond, E.R. Lehman, S.M. Ferreira and R.J. van Aarde, Elephant numbers in the Kafue National Park, Zambia, Pachyderm 39 (2005), pp. $50-56$. 
Hanks, 1979 J. Hanks, A Struggle for Survival: The Elephant Problem, Struik Publishers, Cape Town, South Africa (1979).

Hanks, 2001 J. Hanks, Conservation strategies for Africa's large mammals, Reproduction Fertility and Development 13 (2001), pp. 459-468.

Hanks et al., 1981 J. Hanks, W.D. Densham, G.L. Smuts, J.F. Jooste, S.C.J. Joubert, P. le Roux and P.le S. Milstein, Management of locally abundant large mammals: the South African experience. In: P.A. Jewell and S. Holt, Editors, Problems in Management of Locally Abundant Wild Mammals, Academic Press, New York (1981), pp. 21-56.

Hanski, 1999 I. Hanski, Metapopulation Ecology, Oxford Series in Ecology and Evolution, Oxford University Press, Oxford (1999).

Hanski, 2004 I. Hanski, Metapopulation theory, its use and misuse, Basic and Applied Ecology 5 (2004), pp. 225-229.

Haynes, 1987 G. Haynes, Proboscidean die-offs and die-outs: age profiles in fossil collections, Journal of Archaeological Research 14 (1987), pp. 659-668.

Haynes, 1988 G. Haynes, Longitudinal studies of African elephant death and bone deposits, Journal of Archaeological Research 15 (1988), pp. 131-157.

Hellgren et al., 2005 E.C. Hellgren, D.P. Onorato and J.R. Skiles, Dynamics of a black bear population within a desert metapopulation, Biological Conservation 122 (2005), pp. 131-140.

Herremans, 1995 M. Herremans, Effects of woodland modification by African elephant Loxodonta africana on bird diversity in northern Botswana, Ecography 18 (1995), pp. 440-454.

Hess, 1994 G.R. Hess, Conservation corridors and contagious disease: a cautionary note, Conservation Biology 8 (1994), pp. 256-262.

Hoare, 1999 R.E. Hoare, Determinants of human-elephant conflict in a land-use mosaic, Journal of Applied Ecology 36 (1999), pp. 689-700.

Hoare and du Toit, 1999 R.E. Hoare and J.T. du Toit, Coexistence between people and elephants in African savannas, Conservation Biology 13 (1999), pp. 633-639.

Hofmeyr, 2003 Hofmeyr, M., 2003. Translocation as a management tool for control of elephant populations. In: Proceedings of the First Workshop on the Control of Wild Elephant Populations, Utrecht University, Netherlands.

$<$ http://elephantpopulationcontrol.library.uu.nl/paginas/frames.html> (accessed 5 April 2006). 
Illius and O'Connor, 2000 A.W. Illius and T.G. O'Connor, Resource heterogeneity and ungulate population dynamics, Oikos 89 (2000), pp. 283-294.

Lamprey et al., 1967 H.F. Lamprey, P.E. Glover, H.I.M. Turner and R.H.V. Bell, Invasion of the Serengeti National Park by elephants, East African Wildlife Journal 5 (1967), pp. 151-166.

Laws, 1970 R.M. Laws, Elephants as agents of habitat and landscape change in East Africa, Oikos 21 (1970), pp. 1-15.

Laws et al., 1970 R.M. Laws, I.S.C. Parker and R.C.B. Johnstone, Elephants and habitats in north Bunyoro, Uganda, East African Wildlife Journal 8 (1970), pp. 163-180.

Leuthold, 1976 W. Leuthold, Age structure of elephants in Tsavo National Park, Kenya, Journal of Applied Ecology 13 (1976), pp. 435-444.

Lindeque, $1991 \mathrm{M}$. Lindeque, Age structure of the elephant population in Etosha National Park, Namibia, Madoqua 18 (1991), pp. 27-32.

Lindeque and Lindeque, 1991 M. Lindeque and P.M. Lindeque, Satellite tracking of elephants in northwestern Namibia, African Journal of Ecology 29 (1991), pp. 196-206.

Lindsay, 2003 K. Lindsay, Elephants and habitats: the need for clear objectives, Pachyderm 16 (2003), pp. 34-40.

Lombard et al., 2001 A.T. Lombard, C.F. Johnson, R.M. Cowling and R.L. Pressey, Protecting plants from elephants: botanical reserve scenarios within the Addo Elephant National Park, South Africa, Biological Conservation 102 (2001), pp. 191-203.

McComb et al., 2001 K. McComb, C. Moss, S.M. Durant, L. Baker and S. Sayialel, Matriarchs as repositories of social knowledge in African elephants, Science 292 (2001), p. 491.

Mittermeier et al., 2003 R.A. Mittermeier, C.G. Mittermeier, T.M. Brooks, J.D. Pilgrim, W.R. Konstant, G.A.B. da Fonseca and C. Kormos, Wilderness and biodiversity conservation, Proceedings of the National Academy of Sciences of the United States of America 100 (2003), pp. 10309-10313.

Newmark et al., 1994 W.D. Newmark, D.N. Manyanza, G.M. Gamassa and H.I. Sariko, Community wildlife management around protected areas in Tanzania: human density as a predictor, Conservation Biology 8 (1994), pp. 249-255.

Novaro et al., 2005 A.J. Novaro, M.C. Funes and R.S. Walker, An empirical test of source-sink dynamics induced by hunting, Journal of Applied Ecology 42 (2005), pp. 910-920. 
O’Connell-Rodwell et al., 2000 C.E. O’Connell-Rodwell, T. Rodwell, M. Rice and L.A. Hart, Living with the modern conservation paradigm: can agricultural communities coexist with elephants? A five-year case study in East Caprivi, Namibia, Biological Conservation 93 (2000), pp. 381-391.

Ogutu and Owen-Smith, 2003 J.A. Ogutu and N. Owen-Smith, ENSO, rainfall and temperature influences on extreme population declines among African savannah ungulates, Ecology Letters 6 (2003), pp. 412-419.

Osborn and Parker, 2003 F.V. Osborn and G.E. Parker, Towards an integrated approach for reducing the conflict between elephants and people: a review of current research, Oryx 37 (2003), pp. 80-84.

Owen-Smith, 1983 R.N. Owen-Smith, Dispersal and dynamics of large herbivores in enclosed areas: implications for management. In: R. Owen-Smith, Editor, Management of Large Mammals in African Conservation Areas, Haum Educational Publishers, Pretoria, South Africa (1983), pp. 127-144.

Owen-Smith, 1996 R.N. Owen-Smith, Ecological guidelines for waterpoints in extensive protected areas, South African Journal of Wildlife Research 26 (1996), pp. 107-112.

Parker and Graham, 1989 I.S.C. Parker and A.D. Graham, Elephant decline downward trends in African elephant distribution and numbers (Part II), International Journal of Environmental Studies 35 (1989), pp. 13-26.

Pickett et al., 2003 T.A. Pickett, M. Cadenasso and T. Benning, Biotic and abiotic variability as key determinants of savannah heterogeneity at multiple spatiotemporal scales. In: J.T. du Toit, K.H. Rogers and H.C. Biggs, Editors, The Kruger Experience: Ecology and Management of Savanna Heterogeneity, Island Press, Washington, DC (2003), pp. 22-40.

Pienaar et al., 1966 U.deV. Pienaar, P. van Wyk and N. Fairall, An aerial census of elephant and buffalo in the Kruger National Park, and the implications thereof on intended management schemes, Koedoe 9 (1966), pp. 40-107.

Pimm and van Aarde, 2001 S.L. Pimm and R.J. van Aarde, African elephants and immunocontraception, Nature 411 (2001), p. 766.

Prins and van der Jeugd, 1993 H.H.T. Prins and H.P. van der Jeugd, Herbivore population crashes and woodland structure in East Africa, Journal of Ecology 81 (1993), pp. 305-314.

Pulliam, 1988 H.R. Pulliam, Sources, sinks, and population regulation, American Naturalist 132 (1988), pp. 652-661. 
Pullin et al., 2004 A.S. Pullin, T.M. Knight, D.A. Stone and K. Charman, Do conservation managers use scientific evidence to support their decision-making?, Biological Conservation 119 (2004), pp. 245-252.

Roberts and Travers, 2004 Roberts, A.M., Travers, W., 2004. There's no place like home. "The Swazi 11": a case study in the global trade in live elephants. In: Proceedings of the XIXth International Congress of Zoology, Beijing, China.

$<$ http://www.globalzoology.org/elephant.doc> (accessed 5 April 2006).

Rogers, 2003 K. Rogers, Adopting a heterogeneity paradigm. Implications for management of protected savannas. In: J.T. du Toit, K.H. Rogers and H.C. Biggs, Editors, The Kruger Experience: Ecology and Management of Savanna Heterogeneity, Island Press, Washington, DC (2003), pp. 41-58.

Roth and Douglas-Hamilton, 1991 H.H. Roth and I. Douglas-Hamilton, Distribution and status of elephants in West Africa, Mammalia 55 (1991), pp. 489-527.

Scholes et al., 2003 R. Scholes, W. Bond and H.C. Eckhardt, Vegetation dynamics in the Kruger ecosystem. In: J.T. du Toit, K.H. Rogers and H.C. Biggs, Editors, The Kruger Experience: Ecology and Management of Savanna Heterogeneity, Island Press, Washington, DC (2003), pp. 242-262.

Sinclair, 2003 A.R.E. Sinclair, Mammal population regulation, keystone processes and ecosystem dynamics, Philosophical Transactions of the Royal Society of London 358 (2003), pp. 1729-1740.

Sitati et al., 2005 N.W. Sitati, M.J. Walpole and N. Leader-Williams, Factors affecting susceptibility to crop raiding by African elephants: using a predictive model to mitigate conflict, Journal of Applied Ecology 42 (2005), pp. 1175-1182.

Skarpe et al., 2004 C. Skarpe, P.A. Aarrestad, H.P. Andreassen, S.S. Dhillion, T. Dimakatso, J.T. du Toit, D.J. Halley, H. Hytteborn, S. Makhabu, M. Mari, W. Marokane, G. Masunga, D. Modise, S.R. Moe, R. Mojaphoko, D. Mosugelo, S. Motsumi, G. NeoMahupeleng, M. Ramotadima, L. Rutina, L. Sechele, T.B. Sejoe, S. Stokke, J.E.

Swenson, C. Taolo, M. Vandewalle and P. Wegge, The return of the giants: ecological effects of an increasing elephant population, Ambio 33 (2004), pp. 276-282.

Slotow et al., 2000 R. Slotow, G. van Dyk, J. Poole, B. Page and A. Klocke, Older bull elephants control young males, Nature 408 (2000), pp. 425-426.

Slotow et al., 2005 R. Slotow, M.E. Garaï, B. Reilly, B. Page and R.D. Carr, Population dynamics of elephants re-introduced to small fenced reserves in South Africa, South African Journal of Wildlife Research 35 (2005), pp. 23-32.

Stephenson, 2004 P.J. Stephenson, The future for elephants in Africa. In: N. Burgess, J. d'Amico Hales, E. Underwood, E. Dinerstein, D. Olson, I. Itoua, J. Schipper, T. Ricketts 
and K. Newman, Editors, Terrestrial Ecoregions of Africa and Madagascar - A Conservation Assessment, Island Press, Washington, DC (2004), pp. 133-136.

Stiles, 2004 D. Stiles, The ivory trade and elephant conservation, Environmental Conservation 31 (2004), pp. 309-321.

Surovell et al., 2005 T. Surovell, N. Waguespack and P.J. Brantingham, Global archaeological evidence for proboscidean overkill, Proceedings of the National Academy of Sciences of the United States of America 102 (2005), pp. 6231-6236.

Thomas and Kunin, 1999 C.D. Thomas and W.E. Kunin, The spatial structure of populations, Journal of Animal Ecology 68 (1999), pp. 647-657.

van Aarde et al., 1999 R.J. van Aarde, I. Whyte and S.L. Pimm, The consequences of culling for the dynamics of the African elephant population of Kruger National Park, Animal Conservation 2 (1999), pp. 287-294.

van Aarde et al., 2003 van Aarde, R.J., Killian, W., Pimm S., 2003. The dynamics of savanna elephants in Etosha National Park in northern Namibia. Annual report 2002. Unpublished report to US Fish and Wildlife Service, Conservation Ecology Research Unit, University of Pretoria, South Africa.

van de Koppel and Prins, 1998 J. van de Koppel and H.H.T. Prins, The importance of herbivore interactions for the dynamics of African savanna woodlands: an hypothesis, Journal of Tropical Ecology 14 (1998), pp. 565-576.

van Wyk and Fairall, 1969 P. van Wyk and N. Fairall, The influence of the African elephant on the vegetation of the Kruger National Park, Koedoe 12 (1969), pp. 57-89.

Walker, 1989 B. Walker, Diversity and stability in ecosystem conservation. In: D. Western and M. Pearl, Editors, Conservation for the 21st Century, Oxford University Press, Oxford (1989), pp. 121-130.

Walker et al., 1987 B.H. Walker, R.H. Emslie, R.N. Owen-Smith and R.J. Scholes, To cull or not to cull: lessons from a southern African drought, Journal of Applied Ecology 24 (1987), pp. 381-401.

Western, 1989 D. Western, The ecological role of elephants in Africa, Pachyderm 12 (1989), pp. 42-46.

Western, 2003 D. Western, Conservation science in Africa and the role of international collaboration, Conservation Biology 17 (2003), pp. 11-19.

Western and Gichohi, 1989 D. Western and H. Gichohi, Segregation effects and the impoverishment of savannah parks: the case for ecosystem viability analysis, African Journal of Ecology 31 (1989), pp. 269-281. 
Western and Maitumo, 2004 D. Western and D. Maitumo, Woodland loss and restoration in a savannah park: a 20-year experiment, African Journal of Ecology 42 (2004), pp. $111-121$.

Whyte, 2004 I.J. Whyte, Ecological tests of the new elephant management policy for Kruger National Park and expected outcomes, Pachyderm 36 (2004), pp. 99-109.

Whyte and Grobler, 1997 Whyte, I.J., Grobler, D., 1997. The current status of contraception research in Kruger National Park. Scientific report 13/97. South African National Parks, Skukuza, South Africa.

Whyte et al., 1998 I. Whyte, R. van Aarde and S. Pimm, Managing the elephants of Kruger National Park, Animal Conservation 1 (1998), pp. 77-83.

Whyte et al., 1999 I.J. Whyte, H.C. Biggs, A. Gaylard and L. Braack, A new policy for the management of the Kruger National Park’s elephant population, Koedoe 42 (1999), pp. 111-132.

Whyte et al., 2003 I.J. Whyte, R.J. van Aarde and S.L. Pimm, Kruger’s elephant population: its size and consequences for ecosystem heterogeneity. In: J.T. du Toit, K.H. Rogers and H.C. Biggs, Editors, The Kruger Experience: Ecology and Management of Savanna Heterogeneity, Island Press, Washington, DC (2003), pp. 332-348.

Wikramanayake et al., 2004 E. Wikramanayake, M. McKnight, E. Dinerstein, A. Joshi, B. Gurung and D. Smith, Designing a conservation landscape for tiger in humandominated landscapes, Conservation Biology 18 (2004), pp. 839-844.

Wynberg, 2002 R. Wynberg, A decade of biodiversity conservation and use in South Africa: tracking progress from the Rio Earth Summit to the Johannesburg World Summit on sustainable development, South African Journal of Science 98 (2002), pp. 233-243. 